\title{
KSZTALCENIE ZDALNE, POZIOM STRESU I DOBROSTAN PSYCHICZNY STUDENTÓW PEDAGOGIKI W PIERWSZEJ FAZIE PANDEMII CHOROBY COVID-19
}

Streszczenie: Celem artykułu jest empiryczna weryfikacja zależności między kształceniem zdalnym, zadowoleniem ze studiów, poziomem odczuwanego stresu w czasie pandemii choroby COVID-19 a ogólnym dobrostanem psychicznym studentów. Badania przeprowadzono w czerwcu 2020 roku. Wzięło w nich udział 91 studentów pedagogiki. Analiza wyników badań wskazuje, że ponad 80 proc. studentów pozytywnie ocenia kształcenie zdalne, a 34 proc. jest bardzo zadowolonych ze studiowania pedagogiki. Ocena kształcenia zdalnego przez studentów i poziom ich zadowolenia ze studiów nie ma związku z dobrostanem psychicznym. Ponad połowa badanych studentów prezentuje wysoki poziomu stresu w pierwszej fazie pandemii. Studenci odczuwający niższy poziom stresu lepiej oceniają kształcenie zdalne niż studenci odczuwający wysokie natężenie stresu. Analiza regresji wskazuje, że poziom stresu doświadczany przez studentów jest predyktorem dobrostanu psychicznego. Wraz ze wzrostem natężenia stresu następuje spadek dobrostanu psychicznego. Kryzys zdrowotny wywołany pandemią w istotny sposób wpływa na funkcjonowanie studentów.

Słowa kluczowe: kształcenie zdalne, stres, dobrostan psychiczny, student pedagogiki, pandemia COVID-19.

Rok 2020 zapisze się w historii jako okres globalnego kryzysu, w związku z ogłoszeniem w dniu 11 marca 2020 roku przez Światową Organizację Zdrowia (WHO) pandemii choroby COVID-19. Wirus SARS-CoV-2 bardzo szybko rozprzestrzenił się z Azji do Europy, Ameryki Północnej i dotarł w najbardziej odległe zakątki naszej planety. Globalny zasięg pandemii COVID-19 spowodował dramatyczne zmiany w systemie ochrony zdrowia, ekonomii, gospodarki i funkcjonowania człowieka w wielu obszarach życia.

* Ewa Kulawska, Wydział Nauk Pedagogicznych, Uniwersytet Kardynała Stefana Wyszyńskiego w Warszawie, e-mail: e.kulawska@uksw.edu.pl. 
Większość krajów podjęła działania zmierzające do ograniczenia rozprzestrzeniania się wirusa SARS-CoV-2, zmieniając sposób funkcjonowania szkół, uniwersytetów i działalność wielu instytucji. Ponad 1725 miliarda uczniów i studentów ze 134 krajów czyli 99,9 proc. całej populacji uczącej się doświadczyło zamknięcia instytucji edukacyjnych i rozpoczęła się era edukacji zdalnej organizowanej na niespotykaną do tej pory skalę (Raport UNESCO, 2020). Uczelnie wyższe zawiesiły zajęcia stacjonarne i rozpoczęło się kształcenie $\mathrm{z}$ wykorzystaniem metod i technik kształcenia na odległość, określane jako kształcenie zdalne. Ta sytuacja spowodowała nagłą zmianę codziennego życia studentów, część z nich powróciła do rodzinnych domów, tracąc bezpośredni kontakt z rówieśnikami i wykładowcami, życie studenckie zostało zawieszone i ograniczone zostały do minimum kontakty międzyludzkie w wyniku krajowego lockdown. Ogólnoświatowy kryzys zdrowotny wymusił zmianę codziennych zachowań dużych grup społecznych. Ponadto w długim okresie czasu może on powodować znaczne obciążenia psychologiczne jednostki (Bavel i in. 2020).

Jedną $\mathrm{z}$ istotnych zmian w naszym codziennym zachowaniu była ogłoszona konieczność utrzymywania dystansu społecznego, która miała na celu spowolnienie rozprzestrzeniania się wirusa SARS-CoV-2, aby system opieki zdrowotnej nie uległ załamaniu. Jednocześnie wiadomo, że utrzymująca się izolacja społeczna studentów może wpływać negatywnie na ich dobrostan psychologiczny i zdrowie psychiczne. Wymaganie dystansowania się od innych pozostaje w sprzeczności $\mathrm{z}$ jedną z podstawowych potrzeb ludzkich, jaką jest potrzeba kontaktu $\mathrm{z}$ innymi ludźmi. Relacje międzyludzkie pomagają regulować emocje, radzić sobie ze stresem i zachować odporność w trudnych chwilach, są one częścią tożsamości osobistej i społecznej. Związki z innymi ludźmi są źródłem satysfakcji z życia, sprzyjają zdrowiu psychicznemu i fizycznemu (Wojciszke 2011). Ryan i Deci (2000) wskazują, że potrzeba odczuwania przynależności i więzi z innymi oraz doświadczania wspólnoty jest ważną, wrodzoną potrzebą psychologiczną każdego człowieka. Dane z ogólnopolskich badań w ramach projektu „Diagnoza społeczna” (Czapiński, Panek 2015) wskazują, że liczba przyjaciół jest najsilniejszym predyktorem szczęścia i zadowolenia $\mathrm{z}$ życia. $Z$ drugiej strony samotność i izolacja społeczna zwiększają obciążenie stresem i często mają szkodliwy wpływ na zdrowie psychiczne, sercowo-naczyniowe i immunologiczne (Hawkley, Cacioppo 2010). W kategoriach psychologicznych samotność jest rozumiana jako subiektywny stan, w którym nie doświadcza się wystarczającej więzi społecznej, podczas gdy izolacja jest obiektywnym brakiem interakcji społecznych. Wymuszone sytuacją pandemii choroby COVID-19 dystansowanie się od innych ludzi grozi zwiększeniem poczucia samotności i może mieć negatywne długoterminowe konsekwencje zdrowotne. Należy podkreślić fakt, że więź społeczna jest możliwa nawet wtedy, gdy ludzie są fizycznie oddzieleni. Interakcje on-line mogą również sprzyjać poczuciu więzi, a otrzymywanie, jak i udzielanie wsparcia za pomocą środków komunikacji elektronicznej (on-line) może poprawiać samopoczucie psychiczne (Dore i in. 2017). Konkluzje 
sformułowane przez Waytz i Gray (2018) wskazują, że technologie, które zapewniają kontakt diadyczny i synchroniczny mogą w pewnych warunkach (zależnych od wieku odbiorcy/nadawcy, jakości wcześniejszej relacji) sprzyjać rozwijaniu empatii i więzi społecznej. Z kolei inne badania wskazują, że nadmierne, pasywne korzystanie z mediów społecznościowych może nie wpływać na pozytywne poczucie więzi społecznej (Helliwell, Huang 2013; Verduyn i in. 2015).

W obliczu pandemii choroby COVID-19 wszyscy doświadczamy przewlekłej, długotrwałej sytuacji stresowej. Badania ostatnich lat wskazują, że to nie rodzaj lub natężenie stresu decyduje o jego wpływie na nasze funkcjonowanie, ale raczej indywidualne nastawienie i ocena sytuacji stresowej może decydować o jakości naszego życia (Crum i in. 2020). Nastawienie i nadmierna koncentracja na stresorze, jakim jest możliwość zakażenia się koronawirusem, może wpływać negatywnie na stan fizjologiczny organizmu i zwiększać podatność na zakażenie, podczas gdy pozytywne, adaptacyjne podejście do sytuacji stresowej może zwiększać pozytywne emocje, zmniejszać negatywne objawy zdrowotne, prowadzić do reorganizacji naszego życia, ustalenia nowych priorytetów i większej afirmacji życia (Tedeschi, Calhoun 2004).

Stres jest definiowany jako „szczególna relacja pomiędzy człowiekiem a środowiskiem, w której osoba dokonuje oceny sytuacji jako obciążającej lub przekraczającej jej zasoby" (Lazarus, Folkman 1984, s.19). Ludzie doświadczający takich samych sytuacji społecznych i życiowych różnią się w postrzeganiu stresu i sposobie radzenia sobie z nim. Indywidulane umiejętności i cechy, takie jak: wysoka samoocena i poczucie własnej skuteczności mogą przeciwdziałać doświadczaniu wysokiego poziomu stresu w życiu codziennym (Moksnes i in. 2010; Bandura 1977). Samoregulacja i samokontrola mają kluczowe znaczenie w radzeniu sobie ze stresem w ciągu życia (Baines i in. 2013; Dębska, Guła-Kubiszewska 2005; Heszen-Niejodek 2020; Schiep i in. 2013). Oprócz cech indywidualnych decydujących o reakcji na sytuację stresową, zdarzają się pewne wydarzenia życiowe, które z dużym prawdopodobieństwem wywołują stres u większości ludzi. Należą do nich sytuacje związane z gwałtownymi zmianami w życiu (utrata pracy, śmierć bliskiej osoby, rozwód) oraz takie, nad którymi nie mamy kontroli (katastrofy, wypadki), i sytuacje o wysokim poziomie niejednoznaczności. W grupie uczniów i studentów sytuacje wymagające przystosowania się do nowych warunków to np. zmiana szkoły, przejście na wyższy etap edukacji (np. ze szkoły średniej na studia) (Taylor i in. 2013). Obecnie nowym pytaniem jest, czy przejście na naukę zdalną, zmiana okoliczności i warunków życia, może podwyższać poziom stresu wśród studentów. Najnowsze badania wskazują, że pandemia COVID-19 ma taki właśnie wpływ, jak również powoduje obniżenie nastroju (Bavel i in. 2020; Charles i in. 2021; Garfin i in. 2020. Badania Charles i in. (2021) obejmowały grupę 148 studentów (wiosna 2020) i 352 studentów (jesień 2020) i zostały porównane z wynikami badań 240 studentów uzyskanymi na jesieni 2019 roku. Analizy porównawcze pozwoliły na ustalenie, że studenci na wiosnę 2020 deklarowali zaburzenia nastroju, wyższe natężenie stresu 
i większe spożycie alkoholu niż w okresie przed pandemią, a obawy dotyczące możliwości zachorowania na COVID-19 były związane z niższym dobrostanem psychicznym studentów. Ciekawym wynikiem było ustalenie, że samopoczucie studentów na jesieni 2020 roku było podobne do tego sprzed pandemii choroby COVID-19 w zakresie wyżej wymienionych symptomów.

Wcześniejsze badania (przed pandemią) nad stresem w grupie studentów wskazywały, że subiektywne odczuwanie stresu w czasie studiów jest przeważającym doświadczeniem dużej grupy studiujących (Pierceall i in. 2007). Podczas gdy umiarkowany poziom stresu (eustres) może przynosić pozytywny efekt motywujący do działania i sprzyjać wzrostowi osiągnięć studenckich, to wysoki i stały poziom stresu (dystres) związany jest z niepowodzeniami w czasie studiowania i rezygnacją $z$ kontynuowania studiów (Struthers i in. 2000; Zajacova i in. 2005). Interesujące badania w formie on-line przeprowadzono na początku pandemii choroby COVID-19 w 26 krajach i zebrano dane empiryczne od 53524 osób (od 30 marca do 6 kwietnia 2020 roku). Wyniki wskazują, że wyższe natężenie stresu było charakterystyczne dla młodszych osób, głównie kobiet, osób o niższym poziomie wykształcenia, mieszkających samotnie, a także dla osób posiadających więcej dzieci i żyjących w krajach o wysokim wskaźniku zachorowań na COVID-19 (Kowal i in. 2020).

Sytuacja pandemii choroby COVID-19 i związana z nią konieczność izolacji społecznej i nauki zdalnej na uniwersytetach stworzyła warunki swoistego „eksperymentu" umożliwiającego ustalenie, w jaki sposób młodzi dorośli w wieku 20-25 lat radzą sobie w sytuacji globalnego kryzysu zdrowotnego. Badania Elmera, Mepham, Stadtfeld (2020) prowadzone w Szwajcarii, a mające formę badań podłużnych, dotyczyły porównania uzyskanych wyników w zakresie interakcji społecznych i zdrowia psychicznego studentów w roku $2018(N=54), 2019$ (dwukrotny pomiar) i w czasie pandemii - w kwietniu 2020 roku $(N=212)$. Zmienna interakcji społecznych dotyczyła następujących wymiarów: przyjaźń, wsparcie emocjonalne, wsparcie informacyjne, wspólne studiowanie, wzajemne przyjazne relacje. Założono, że zmniejszenie i ograniczenie relacji społecznych w wyniku kryzysu zdrowotnego spowoduje wzrost wskaźników zdrowia psychicznego, takich jak: symptomy depresyjne, stres, lęk, samotność. Analizy statystyczne potwierdziły hipotezy, że pandemia choroby COVID-19 wyzwoliła lęk o zdrowie swoje i najbliższych, obawy o przyszłość, a brak interakcji społecznych, wsparcia emocjonalnego oraz fizyczna izolacja były związane z negatywnym funkcjonowaniem psychologicznym. Na uwagę zasługuje wynik wskazujący, że miesiąc izolacji społecznej spowodował wzrost symptomów depresyjnych, poziomu odczuwanego stresu, samotności studentów w porównaniu do okresu sprzed pandemii choroby COVID-19 (wrzesień 2019). Wyniki badań pokazują, że studenci, którzy w większym stopniu martwili się o rodzinę i przyjaciół, mieli wyższe wskaźniki depresyjności, odczuwali większy stres w życiu codziennym. Autorzy badania ustalili, że izolacja społeczna studentów współwystępuje z wyższym poziomem lęku i samotności. Studenci, którzy mieli mniejszą liczbę przyjaciół i mieszkali samotnie, byli bardziej narażeni na 
wyższe wskaźniki w odniesieniu do symptomów depresyjnych. Z kolei studenci, którzy utrzymywali intensywne kontakty on-line z przyjaciółmi i otrzymywali od nich wsparcie emocjonalne, wykazywali mniejsze wskaźniki objawów depresji i samotności. Okazało się, że kobiety-studentki częściej doświadczały negatywnych stanów niż mężczyźni, pomimo że utrzymywały silniejsze więzi społeczne niż mężczyźni-studenci. Konkluzja z tych badań wskazuje, że kryzys zdrowotny wywołany pandemią choroby COVID-19 ma negatywny wpływ na więzi społeczne i zdrowie psychiczne studentów w czasie wprowadzonych ograniczeń w życiu społecznym (Elmer i in. 2020). Zbliżone wyniki uzyskano w badaniach francuskich 291 studentów pierwszego roku, jednakże zauważono, że studenci, którzy powrócili do domów rodzinnych wraz z zamknięciem uniwersytetów (ponad 50 proc. badanej grupy), znacznie lepiej pod względem samopoczucia psychicznego znosili sytuację obostrzeń i rygoru izolacji w czasie pandemii, niż studenci, którzy mieszkali samotnie. W tej grupie studentów potwierdzono wyższe wskaźniki lęku i doświadczania stresu (Husky i in. 2020). Z kolei w podłużnych badaniach, prowadzonych wśród 255 studentów angielskich od jesieni 2019 do jesieni 2020 roku, podjęto próbę ustalenia związków między dobrostanem psychicznym, odczuwanym stresem, aktywnością fizyczną i siedzącym trybem życia w okresie pandemii. Wyniki badań potwierdzają hipotezy, że w czasie dziewięciu miesięcy pandemii aktywność fizyczna studentów spadła i dobrostan psychiczny studentów uległ pogorszeniu, natomiast wzrósł poziom stresu (Savage i in. 2021).

Dobrostan psychiczny jest osiowym konstruktem w zakresie psychologii pozytywnej i ma istotne znaczenie dla funkcjonowania człowieka w aspekcie indywidualnym i społecznym. Diener i Seligman (2004, s. 1) definiują dobrostan psychiczny jako „pozytywną ocenę życia przez ludzi, obejmującą pozytywne emocje, zaangażowanie, satysfakcję i znaczenie". Ryan i Deci (2001) charakteryzują dobrostan psychiczny jako optymalne funkcjonowanie psychologiczne i doświadczenie, i wskazują na jego aspekt hedonistyczny (koncentrujący się na szczęściu i zadowoleniu z życia) oraz eudajmonistyczny (koncentrujący się na poczuciu sensu życia i samorealizacji). Dobrostan psychiczny odgrywa ważną rolę we wszystkich grupach zawodowych, ale szczególne znaczenie ma w pracy nauczyciela, i dlatego analiza tego wymiaru w odniesieniu do studentów pedagogiki może mieć kluczową wartość w przygotowaniu do przyszłej pracy nauczycielskiej (Kulawska 2019). Uwzględniając tę perspektywę, bardzo ważne jest zbadanie, jak kryzys zdrowotny wywołany chorobą COVID-19 wpływa na dobrostan psychiczny studentów, w jaki sposób przyszli pedagodzy radzą sobie w sytuacji stresowej związanej w ograniczeniami kontaktu i zmianą formy studiowania. Ustalenia te o charakterze diagnostycznym wskażą, czy i w jakim stopniu są oni przygotowani w przyszłości na ewentualne inne, nieprzewidywalne sytuacje kryzysowe o zasięgu globalnym. 


\section{Cel, metoda i procedura badań}

Celem podjętych badań jest analiza funkcjonowania studentów w pierwszej fazie rozwoju pandemii choroby COVID-19 (od marca do czerwca 2020 roku) w odniesieniu do następujących aspektów: oceny kształcenia zdalnego w opiniach studentów pedagogiki, określenia nasilenia przeżywanego stresu i dobrostanu psychicznego w czasie wprowadzonych restrykcji w Polsce oraz poziomu zadowolenia ze studiów pedagogicznych. Kolejnym celem jest opisanie zależności pomiędzy analizowanymi zmiennymi, ustalenie predyktorów dobrostanu psychicznego studentów pedagogiki w pierwszych miesiącach nauki zdalnej. Podstawowy problem badawczy polega na określeniu, czy istnieje związek między studiowaniem zdalnym, zadowoleniem ze studiów, odczuwanym stresem w czasie pandemii choroby COVID-19 a ogólnym dobrostanem psychicznym studentów.

W celu zebrania opinii o kształceniu zdalnym, które rozpoczęło się wraz z zamknięciem uczelni wyższych, zastosowano autorski kwestionariusz ankiety „Studiowanie zdalne w czasie pandemii”. Składa się on z 17 pytań dotyczących jakości studiowania z wykorzystaniem metod i technik kształcenia na odległość. Studenci oceniali jakość kształcenia zdalnego w porównaniu do studiowania stacjonarnego, zakres materiału do samodzielnej nauki, wsparcie, pomoc udzielaną przez wykładowców i kontakt z nimi, trudności techniczne i warunki domowe w studiowaniu zdalnym (dostęp do sprzętu i internetu). Respondenci udzielali odpowiedzi w skali pięciostopniowej (od 1 - „zdecydowanie nie zgadzam się”, do 5 - „Zdecydowanie zgadzam się"). Zakres możliwych punktów do zdobycia wynosił od 17 do 85. Im wyższy wynik uzyskiwali studenci, tym większa była akceptacja i brak trudności w studiowaniu zdalnym. Dodatkowo sprawdzono poziom zadowolenia ze studiów i zastosowano skalę Academic Scale autorstwa Lent, Singley i in. (2005) w tłumaczeniu Janusza Surzykiewicza. Skala składa się z siedmiu twierdzeń dotyczących poziomu satysfakcji ze studiów. Studenci udzielali odpowiedzi umieszczanychw sześciostopniowej skali: od 1- „zdecydowanie nie zgadzam się”, do 6 - zdecydowanie zgadzam się. Przykładowe stwierdzenia: „jestem zadowolony z wyboru kierunku studiów”, ,jestem entuzjastycznie nastawiony do przedmiotu nauki na moim kierunku studiów". Zakres możliwych wyników waha się od siedmiu do 42 punktów.

Do pomiaru natężenia doświadczanego stresu w okresie pandemii zastosowano "Skalę Odczuwanego Stresu PSS-10" (The Perceived Stress Scale, Cohen, Kamarck, \& Mermelstein, 1983), w adaptacji Z. Juczyńskiego i N. Ogińskiej-Bulik). Skala PSS-10 składa się z 10 twierdzeń $\mathrm{w}$ formie samopisu dotyczących oceny poziomu sytuacji stresowych, których osoba badana doświadczyła w ciągu ostatniego miesiąca. Odpowiedzi są udzielane w pięciostopniowej skali Likerta (od „nigdy = o do bardzo często $=5$ ) i opisują natężenie odczuwania stresu w życiu codziennym przez studentów, a także ocenę, na ile postrzegają oni swoje życie jako nieprzewidywalne, niemożliwe do kontroli i trudne do zniesienia. Wyniki w kwestionariuszu wahają 
się od o do 40 punktów. Im wyższy wynik uzyska respondent, tym wyższy jest poziom odczuwanego stresu. Skala PSS-10 jest powszechnie stosowanym narzędziem w badaniach polskich i międzynarodowych (Stecz, Chanduszko-Skalska 2010; Kadzikowska-Wrzosek 2012; Cohen i in. 2012; Crum i in.2020; Son $i$ in. 2020).

Ocenę dobrostanu psychicznego przeprowadzono za pomocą skali The WarwickEdinburgh Mental Well-being Scale (WEMWBS), w tłumaczeniu E. Kulawskiej. Skala WEMWBS została skonstruowana przez Ruth Tennant, Sarah Stewart-Brown i współpracowników (Tennant i in. 2007), a prawa autorskie należą do NHS Health Scotland, University of Warwick i University of Edinburgh. Uzyskano pozwolenie na zastosowanie skali w prezentowanych badaniach poprzez rejestrację zgłoszenia na Uniwersytecie w Warwick. Skala składa się z 14 stwierdzeń odnoszących się do aspektu hedonistycznego i eudajmonistycznego dobrostanu psychicznego, opisujących pozytywne odczucia (afekty), takie jak: optymizm, zadowolenie, radość, odprężenie oraz satysfakcjonujące relacje interpersonalne i pozytywne funkcjonowanie (energia do działania, samoakceptacja, autonomia, rozwój osobisty, poczucie bycia kompetentnym). Osoby badane są proszone o zaznaczenie odpowiedzi, która najlepiej opisuje ich odczucia z ostatnich dwóch tygodni w pięciostopniowej skali Likerta (1 - „nigdy”, 2 - rzadko, 3 - czasami, 4-często, 5 - zawsze). Każdej $\mathrm{z}$ odpowiedzi przypisano liczbę od 1 do 5 , minimalna liczba punktów do zdobycia wynosi 14, maksymalna 70. Wyższa liczba zdobytych punktów oznacza wyższy poziom dobrostanu psychicznego.

Badania zostały przeprowadzone w czerwcu 2020 roku, w trzecim miesiącu nauki zdalnej na uczelniach wyższych w Polsce. W badaniach wzięło udział 91 studentów pedagogiki, przygotowujących się do zawodu nauczyciela przedszkola i klas I-III w jednej z warszawskich uczelni wyższych. Udział studentów w badaniach był dobrowolny $i$ anonimowy i polegał na udzieleniu odpowiedzi w ankiecie on-line zamieszczonej na platformie edukacyjnej wykorzystywanej w kształceniu zdalnym (dostępnej tylko dla studentów pedagogiki).

\section{Analiza wyników badań własnych}

Wiek studentów, którzy wzięli udział w badaniu $(N=91)$, wahał się od 19 do 43 lat, średnia wieku wynosiła $M=23,4$ roku, zaś odchylenie standardowe $-S D$ $=4,94$. Na studiach pedagogicznych przeważają kobiety i podobnie wśród osób badanych większość stanowiły studentki (86 kobiet - 94,5 proc. ogółu), niż studenci-mężczyźni (5 osób - 5,5 proc. ogółu badanych). Z badanej grupy 33 proc. osób studiowało na pierwszym roku, 48 proc. na II roku studiów, 19 proc. na III roku studiów. Większość respondentów (6oproc.) było studentami studiów stacjonarnych, 4oproc. studiowało pedagogikę $\mathrm{w}$ formie niestacjonarnej. Dane socjodemograficzne i miejsce pochodzenia osób badanych wskazują, że ponad 39 proc. studentów mieszka na wsi, 20 proc. - w małych miastach do 20 tys. mieszkańców, 
21 proc. - w miastach do 500 tys. mieszkańców i kolejne 20 proc. w miastach powyżej 500 tys. mieszkańców.

Analizę wyników badań rozpoczęto od ustalenia rozkładu zmiennych, a charakter tego rozkładu został sprawdzony przy użyciu testu Kołmogorowa-Smirowa. Wyniki testu zamieszczono w tabeli 1. Wskazują one, że zmienne: kształcenie zdalne, odczuwany stres, dobrostan psychiczny, zadowolenie ze studiów mają rozkład normalny, co pozwala na zastosowanie testów parametrycznych, takich jak: korelacja $r$ Pearsona, test $t$ dla prób niezależnych, jednoczynnikowa analiza wariancji Anova, analiza regresji liniowej. Analizy statystyczne zostały przeprowadzone przy pomocy programu IBM SPSS wersja 27. Za istotne statystycznie przyjęto prawdopodobieństwo testowe na poziomie $p<0.05$, za wysoce istotne na poziomie $p<0,01$ i $p<0,001$.

Tabela 1. Test normalności rozkładu Kołmogorowa-Smirnowa dla analizowanych zmiennych

\begin{tabular}{|l|c|c|c|}
\hline & Wynik testu K-S & df & Istotność \\
\hline Kształcenie zdalne & 0,53 & 91 & 0,2 \\
\hline Odczuwany stres & 0,62 & 91 & 0,2 \\
\hline Dobrostan psychiczny & 0,78 & 91 & 0,2 \\
\hline Zadowolenie ze studiów & 0,89 & 91 & 0,08 \\
\hline
\end{tabular}

Źródło: opracowanie własne.

Pierwszym krokiem w analizie zebranego materiału empirycznego jest obliczenie średnich, odchylenia standardowego i korelacji między zmiennymi. Wyniki tych analiz przedstawiono $\mathrm{w}$ tabeli $\mathrm{nr}$ 2. Wszystkie zastosowane narzędzia badawcze uzyskały wysokie współczynniki rzetelności alfa Cronbacha (od o,86 do o,9o proc.), które świadczą o wysokiej spójności pytań zawartych w kwestionariuszach. Najsilniejsza ujemna korelacja zachodzi między poziomem odczuwanego stresu a dobrostanem psychicznym $(r=-.568 p<0.001)$, natomiast umiarkowany i ujemny związek występuje miedzy odczuwanym stresem a studiowaniem zdalnym $(r .317$ $p<0.01$ ). Słabsza korelacja, ale istotna statystycznie, zachodzi między studiowaniem zdalnym a zadowoleniem ze studiów $(r=.274 p<0.01)$.

Tabela 2. Statystyki opisowe i rzetelność skal oraz korelacje między zmiennymi

\begin{tabular}{|l|c|c|c|c|c|c|c|}
\hline & $\begin{array}{c}\text { Alfa } \\
\text { Cronbacha }\end{array}$ & $\mathrm{M}$ & $\mathrm{SD}$ & 1 & 2 & 3 & 4 \\
\hline $\begin{array}{l}\text { 1. Kształcenie } \\
\text { zdalne }\end{array}$ & 0,86 & 55,71 & 10,47 & - & $-.317^{* *}$ & .140 & $.274^{* *}$ \\
\hline $\begin{array}{l}\text { 2. Odczuwany } \\
\text { stres }\end{array}$ & 0,89 & 20,12 & 6,63 & $-.317^{* *}$ & - & $-.568^{* * *}$ & -.034 \\
\hline
\end{tabular}




\begin{tabular}{|l|c|c|c|c|c|c|c|}
\hline & $\begin{array}{c}\text { Alfa } \\
\text { Cronbacha }\end{array}$ & $\mathrm{M}$ & $\mathrm{SD}$ & 1 & 2 & 3 & 4 \\
\hline $\begin{array}{l}\text { 3. Dobrostan } \\
\text { psychiczny }\end{array}$ & 0,90 & 50,80 & 8,08 & .140 & $-.568^{* * *}$ & - & .044 \\
\hline $\begin{array}{l}4 . \\
\text { Zadowolenie } \\
\text { ze studiów }\end{array}$ & 0,89 & 32,20 & 5,73 & $.274^{* *}$ & -.034 & .044 & - \\
\hline
\end{tabular}

Źródło: Opracowanie własne.

${ }^{* *} p<0,01 ;{ }^{* *} p<0.001$; Przedstawione korelacje to współczynniki $r$ Pearsona.

W marcu 2020 roku nastąpiła nagła zmiana formy studiowania ze stacjonarnej na zdalną. Zarówno wykładowcy akademiccy, jak i studenci zostali zmuszeni do wypracowania nowej formy prowadzenia zajęć i kontaktu poprzez technologie informacyjne. Po trzech miesiącach funkcjonowania formy studiów na odległość studenci ustosunkowali się i wyrazili swoje opinie na temat studiowania zdalnego w pierwszej fazie pandemii choroby COVID-19. Około 78 proc. studentów uważa, że istnieje zdecydowana różnica między studiowaniem stacjonarnym a zdalnym, a 46 proc. stwierdza, że studiowanie stacjonarne jest bardziej efektywne. Z kolei 44 proc. $z$ badanej grupy studenckiej wskazuje, że studiowanie zdalne przynosi takie same efekty jak przed pandemią. Studenci $(62,7$ proc.) zwracają uwagę, że studia $\mathrm{w}$ formie zdalnej wymagały od nich więcej pracy niż podczas studiowania tradycyjnego, ale większość (7o proc.) stwierdza, że zakres materiału do nauki był podobny jak w czasie zajęć na uczelni. Prawie 45 proc. przyznaje, ze zajęcia prowadzone $\mathrm{w}$ pierwszym okresie pandemii choroby COVID-19 były ciekawe i stymulujące intelektualnie, ale 37 proc. ma odmienne zdanie. Pomimo że połowa ( 53 proc.) studentów bardzo dobrze ocenia kontakt $\mathrm{z}$ wykładowcami w czasie pandemii i ich zaangażowanie w prowadzenie zajęć on-line w drugim kwartale 2020 roku, to 44 proc. preferuje bezpośrednie kontakty z nauczycielami akademickimi. W odniesieniu do aspektu technicznego prowadzenia zajęć zdalnych prawie 89 proc. studentów bardzo dobrze poradziło sobie z dostępem do sprzętu, oprogramowania i internetu, 83 proc wskazało, że miało bardzo dobre warunki w domu do udziału w zajęciach i większość studentów ( 78 proc.) nie potrzebowała udziału $\mathrm{w}$ szkoleniach $\mathrm{w}$ zakresie korzystania $\mathrm{z}$ dostępnych aplikacji używanych $\mathrm{w}$ czasie zajęć zdalnych. Prawie 65 proc. studentów wyraża przekonanie, że studiowanie zdalne mogłoby być kontynuowane w kolejnym roku akademickim.

W grupie studentów pedagogiki średnia akceptacji studiowania zdalnego wynosi $M=55,71, S D=10,47$. Wyodrębniono trzy grupy studentów różniące się poziomem oceny studiowania zdalnego. Najwięcej studentów (57,1 proc.) należy do grupy przypisującej studiowaniu zdalnemu przeciętne/średnie wartości $(M=53,13 ; S D=$ 4,34), następnie 29,7 proc. ocenia studiowanie zdalne bardzo dobrze $(M=68,22$; $S D=4,59$ ), a 13,2 proc. studentów przypisuje oceny niskie tej formie studiowania $(M=38,75 ; S D=5,57)$. Różnice między średnimi w ocenach studiowania zdalnego 
$\mathrm{w}$ trzech grupach studentów są istotne statystycznie, i test $F \mathrm{w}$ analizie wariancji przybiera następujące wartości: $F(2,88)=190,32, p<0,001)$ (tabela trzecia).

Tabela 3. Wyniki jednoczynnikowej analizy wariancji dla zmiennych: kształcenie zdalne, stres, dobrostan psychiczny, zadowolenie ze studiów

\begin{tabular}{|c|c|c|c|c|c|c|}
\hline & Kategorie & $N$ & $M$ & $S D$ & $\begin{array}{c}\text { Analiza } \\
\text { wariancji } \\
F(2 ; 88)\end{array}$ & $p<$ \\
\hline \multirow{3}{*}{$\begin{array}{l}\text { Ocena } \\
\text { kształcenia } \\
\text { zdalnego }\end{array}$} & niska & 12 & 38,75 & 5,57 & \multirow{3}{*}{190,32} & \multirow{3}{*}{0,001} \\
\hline & średnia & 52 & 53,13 & 4,34 & & \\
\hline & wysoka & 27 & 68,22 & 4,59 & & \\
\hline \multirow{3}{*}{$\begin{array}{l}\text { Odczuwany } \\
\text { stres }\end{array}$} & niski & 16 & 10,37 & 2,57 & \multirow{3}{*}{134,35} & \multirow{3}{*}{0,001} \\
\hline & średni & 28 & 16,78 & 1,52 & & \\
\hline & wysoki & 47 & 25,08 & 4,21 & & \\
\hline \multirow{3}{*}{$\begin{array}{l}\text { Dobrostan } \\
\text { psychiczny }\end{array}$} & niski & 13 & 37,46 & 3,59 & \multirow{3}{*}{55,90} & \multirow{3}{*}{0,001} \\
\hline & średni & 76 & 52,58 & 5,69 & & \\
\hline & wysoki & 2 & 70,00 & 0,00 & & \\
\hline \multirow{3}{*}{$\begin{array}{l}\text { Zadowolenie } \\
\text { ze studiów }\end{array}$} & niskie & 10 & 21,40 & 5,18 & \multirow{3}{*}{145,49} & \multirow{3}{*}{0,001} \\
\hline & średnie & 50 & 30,82 & 2,26 & & \\
\hline & wysokie & 31 & 37,90 & 2,53 & & \\
\hline
\end{tabular}

Źródło: opracowanie własne.

Kolejnym krokiem w ocenie funkcjonowania studentów w czasie pierwszych trzech miesięcy pandemii choroby COVID-19 jest określenie poziomu przeżywanego przez nich stresu. Wyniki badań pokazują (tabela trzecia), że zgodnie z normami stenowymi dla skali PSS-10 studenci pedagogiki stwierdzili, że doświadczają wysokiego poziomu stresu $(M=21,12 ; S D=6,63)$. W grupie badanej wyróżniono trzy podgrupy: studenci (17 proc.) o niskim poziomie stresu $(M=10,37 ; S D=2,57)$, średnim (31 proc. studentów) $(M=16,78 ; S D=1,52)$ i wysokim (52 proc. studentów) $(M=25,08 ; S D=4,21)$. Pomiędzy tymi trzema grupami studentów o zróżnicowanym poziomie odczuwanego stresu zachodzą istotne statystycznie różnice, świadczy o tym wynik jednoczynnikowej analizy wariancji Anova $F(2,88)=134,35 ; p<0,001$.

Trzecim analizowanym wymiarem jest poziom dobrostanu psychicznego studentów. Średnia dla całej grupy wynosi $(M=50,80 ; S D=8,08)$. Prawie 84 proc. studentów pedagogiki prezentuje średni dobrostan psychiczny $(M=52,58 ; S D=$ $5,69)$, kolejne 14 proc. studentów charakteryzuje się niskim poziomem dobrostanu $(M=37,46 ; S D=3,59)$, podczas gdy dwa proc. studentów odczuwa wysoki poziom szczęścia i zadowolenia $z$ własnego życia $(M=70,00 ; S D=0,00)$. Zastosowanie analizy wariancji pozwala na stwierdzenie, że między tymi trzema grupami występują różnice istotne statystycznie $(F(2,88)=55,90 ; p<0,001)$. Sytuacja pandemii i zmiana warunków studiowania może mieć związek z poziomem zadowolenia ze 
studiów. Wśród respondentów 11 proc. badanych jest niezadowolonych ze studiów $(M=21,40 ; S D=5,18), 54,9$ proc. studentów jest średnio zadowolonych $(M=30,82$; $S D=2,26)$, a 34 proc. osób badanych jest bardzo zadowolonych ze studiowania pedagogiki w pierwszej fazie pandemii koronawirusa SARS-CoV-2 w Polsce $(M=$ 37,$90 ; S D=2,53$ ). Podobnie jak w przypadku innych wyżej opisanych wyników, występują istotne statystycznie różnice między grupami studentów o zróżnicowanym poziomie zadowolenia ze studiów $(F(2,88=145,49 ; p<0,001)$.

Poszukując odpowiedzi na pytanie, czy kształcenie zdalne w czasie pandemii choroby COVID-19 i zadowolenie ze studiów oraz odczuwany stres mają związek z poczuciem dobrostanu psychicznego, wykonano serię analiz wariancji dla poszczególnych zmiennych. Wyniki Anovy wskazują, że studencka ocena studiowania zdalnego nie ma związku z poziomem dobrostanu psychicznego studentów $(F(2,88)=0,391 ; p<0,978)$. Również zadowolenie ze studiów nie ma związku $\mathrm{z}$ dobrostanem psychicznym $(F(2,88)=0,638 ; p<0,531)$. Wyniki te wskazują, że inne czynniki mają wpływ na poczucie szczęścia i pozytywną ocenę swojego życia młodych osób dorosłych. Ciekawym wynikiem jest zależność między oceną studiowania zdalnego a ogólnym zadowoleniem ze studiów. Uzyskano wynik wskazujący, że ocena studiowania zdalnego ma związek z ogólnym zadowoleniem ze studiów pedagogicznych $\left(F(2,88)=3,00 ; p<0,05, \mathrm{n}^{2}=0,064\right)$. Zauważono, że subiektywny poziom stresu ma związek z dobrostanem psychicznym studentów. Studenci o niskim poziomie odczuwanego stresu charakteryzują się wysokim dobrostanem psychicznym $(M=57,31 ; S D=7,15)$, a studenci doświadczający stresu o wysokim natężeniu w życiu codziennym mają znacznie niższy ogólny dobrostan psychiczny $(M=47,27 ; S D=7,19)$. Wraz ze wzrostem odczuwanego stresu następuje spadek dobrostanu psychicznego $\left(F(2,88)=13,71 ; p<0,001, \eta^{2}=0,238\right)$. Natężenie przeżywanego stresu w sytuacjach życiowych jest oceną subiektywną, dokonywaną przez człowieka i nie dotyczy obiektywnych sytuacji powszechnie uważanych za stresujące (jak np. śmierć bliskiej osoby, utrata pracy). Zauważono jeszcze jedną zależność, w której stres odgrywa istotną rolę w życiu badanych studentów. Studenci, którzy najlepiej ocenili studiowanie zdalne (22 proc.), uzyskali najniższe wyniki w zakresie odczuwanego stresu $(M=17,48 ; S D=4.99)$. $Z$ kolei studenci, których ocena studiowania zdalnego była najniższa (13 proc.), uzyskali najwyższe wyniki w zakresie doświadczania stresu w codzienności $(M=24,5$; $S D=5,99)$. Jednoczynnikowa analiza wariancji okazała się istotna statystycznie pomiędzy tymi dwiema grupami studentów $(F(2,88)=5,15 ; p<0,01)$.

W kolejnym kroku za pomocą analizy regresji poszukiwano odpowiedzi na pytanie, który z uwzględnionych w badaniu czynników (zadowolenie ze studiów, studiowanie w formie zdalnej, poziom odczuwanego stresu) odgrywa istotną rolę w przewidywaniu poziomu dobrostanu psychicznego studentów w w początkowej fazie pandemii choroby COVID-19 (tabela czwarta). 
Tabela 4. Uwarunkowania dobrostanu psychicznego studentów w początkowej fazie pandemii choroby COVID-19

\begin{tabular}{|l|c|c|c|c|c|}
\hline \multicolumn{1}{|c|}{$\begin{array}{c}\text { Model 1. } \\
\text { Predyktory }\end{array}$} & B & $\begin{array}{c}\text { Błąd } \\
\text { standardowy }\end{array}$ & $\beta$ & $t$ & $p<$ \\
\hline Stała & 65.62 & 5.95 & & 11.01 & .001 \\
\hline Stres & -.712 & .113 & -.585 & -6.29 & .001 \\
\hline Zadowolenie ze studiów & .058 & .129 & .039 & .431 & .668 \\
\hline Kształcenie zdalne & 0.43 & .075 & -.056 & .582 & .562 \\
\hline
\end{tabular}

Źródło: opracowanie własne.

$\mathrm{W}$ analizie regresji do modelu 1. wprowadzono trzy zmienne wyjaśniające (predyktory): stres, zadowolenie ze studiów i kształcenie zdalne. Zmienną wyjaśnianą w modelu 1. jest dobrostan psychiczny. Istotnym statystycznie predyktorem okazał się tylko poziom odczuwanego stresu $(\beta=-0,585 ; p<0,001)$. Wartość ujemna współczynnika beta wskazuje, że wraz ze wzrostem odczuwanego stresu następuje spadek ogólnego dobrostanu psychicznego. Pozostałe zmienne wyjaśniające: zadowolenie ze studiów i studiowanie zdalne nie mają związku z odczuwanym dobrostanem psychicznym. Model regresji jest dobrze dopasowany do danych i pozwala na przewidywanie dobrostanu psychicznego na podstawie poziomu subiektywnie odczuwanego stresu $(F(3,87)=14,024 ; p<0,001)$. Zbudowany model wyjaśnia 30 proc. zmienności wariancji zmiennej wyjaśnianej, czyli dobrostanu psychicznego. Oznacza to, że tym samym 70 proc. zmienności dobrostanu psychicznego jest wyjaśniana przez inne czynniki nieuwzględnione w badaniu.

\section{Dyskusja wyników i podsumowanie}

Prowadzone badania miały na celu określenie zależności między zmianą formy studiowania $z$ tradycyjnej na zdalną, koniecznością izolacji i brakiem kontaktów w środowisku akademickim a dobrostanem psychicznym studentów w pierwszej fazie pandemii choroby COVID-19. Wyniki badań wskazują, że zmiana formy studiowania, jak również poziom zadowolenia ze studiów pedagogicznych nie mają związku z poziomem dobrostanu psychicznego studentów. W podobnych badaniach, prowadzonych przed pandemią wśród 400 studentów pedagogiki, uzyskano potwierdzenie, że zachodzi związek między zadowoleniem ze studiów a dobrostanem psychicznym (Kulawska 2019). Być może trzymiesięczny okres studiowania zdalnego jest zbyt krótki, aby w sposób istotny wpłynął na ogólne odczuwanie zadowolenia $\mathrm{z}$ własnego życia. Poza tym pierwszy okres rozprzestrzeniania się wirusa SARS-CoV-2 w 2020 roku był dla wszystkim okresem nieprzewidywalnym, o dużym natężeniu niepewności i stresu, a większość osób była skoncentrowana na zapewnieniu bezpieczeństwa zdrowotnego sobie i najbliższym. Pomimo trudnej sytuacji kryzysowej wywołanej pandemią połowa badanych studentów stwierdza, 
że studiowanie zdalne jest efektywne, a ponad 65 proc. deklaruje chęć kontynuowania takiej formy zdobywania wiedzy.

Ponad połowa badanych studentów odczuwała w tym okresie wysoki poziom stresu, który w istotny sposób wpływa pozostaje w związku $\mathrm{z}$ na poziomem ich dobrostanu psychicznego. Badani, polscy studenci pedagogiki $(N=91)$, uzyskali wyższe średnie wyniki stresu (mierzone tym samym narzędziem PSS-10), niż studenci w USA w czasie pandemii choroby COVID-19 (195 studentów, $M=18,8 ; S D=4,9$; Son i in. 2020) i studenci w Wielkiej Brytanii (524 studentów, $M=19,79 ; S D=6,37$ ). Skala PSS-10 jest szeroko stosowanym narzędziem diagnostycznym w środowisku akademickim, pozwalającym na badania przesiewowe w celu wyłonienia grupy potrzebującej pomocy psychologicznej i wsparcia. Niepokojące jest, że połowa badanych studentów wymaga takiej interwencji. Oczywiście, należy zaznaczyć, że grupa badanych była homogeniczna, obejmowała głównie kobiety, a badania pokazują, że kobiety we wszystkich grupach wiekowych doświadczają wyższego poziomu stresu niż mężczyźni (Kowal i in. 2020; Elmer i in. 2020) Ponadto w pomiarach stresu wśród studentów przed pandemią ustalono, że ta grupa społeczna odznacza się wyższymi wskaźnikami stresu niż ogólna populacja. Taka tendencja została potwierdzona w różnych krajach: Wielkiej Brytanii (Turner i in. 2015), Szwecji (Vaez i in. 2004), USA (Blanco i in. 2008). Badania nad stresem w okresie studiów są istotne z punktu widzenia jego konsekwencji dla funkcjonowania indywidualnego studentów i obserwowanej zależności między stresem a zaburzeniami depresyjnymi i podejmowanymi próbami samobójczymi wśród studentów (Zhang i in. 2015). Ponadto wysoki poziom stresu wpływa na osiągnięcia akademickie, ponieważ obniża koncentrację uwagi i utrudnia zapamiętywanie (Denovan, Macaskill 2016). $\mathrm{W}$ badaniach własnych ustalono, że studenci odczuwający niższy poziom stresu lepiej oceniają studiowanie zdalne niż studenci przeżywający silny stres. Otrzymane wyniki badań własnym korespondują z dotychczasowymi ustaleniami badaczy na temat wpływu pandemii choroby COVID-19 na wzrost poziomu stresu wśród studentów (Bavel i in. 2020; Charles i in. 2021; Garfin i in. 2020; Husky i in. 2020).

Zaskakujący wynik dotyczy poziomu oceny przez studentów swojego życia w kategoriach pozytywnego funkcjonowania psychologicznego, poczucia szczęścia, sensu i samorealizacji. Wysokie wartości dobrostanu psychicznego przypisuje sobie dwa proc. badanych studentów, ponad 80 proc. wskazuje na średnie wartości poczucia dobrostanu. Przed pandemią wyniki wysokie w tym zakresie uzyskało 10 proc. badanych studentów spośród 400-osobowej grupy (Kulawska 2019). Dobrostan psychiczny może być traktowany jako wskaźnik pozytywnej adaptacji do sytuacji kryzysowej (Ryff 2017), zatem spadek wskaźników dobrostanu psychicznego świadczy o trudnościach adaptacyjnych studentów w początkowej fazie pandemii. Dobrostan psychiczny pełni również niezwykle istotną rolę w zawodach pedagoga i nauczyciela. W szeregu badaniach ustalano, że wyższy poziom dobrostanu psychicznego nauczycieli ma związek z lepszym funkcjonowaniem emocjonalnym, poznawczym i samopoczuciem uczniów w szkole (Cornelius-White 
2007; Harding i in. 2019). Wychodząc z tego założenia, poziom dobrostanu psychicznego u studentów pedagogiki może stanowić ważny prognostyczny wskaźnik ich funkcjonowania w zawodzie nauczycielskim. Tezę tą wspierają rozważania Ilskiej, Kołodziej-Zalewskiej (2018), koncentrujące się na ustaleniach, że dobrostan psychiczny jest względnie stałą dyspozycją człowieka, która jest determinowana genetycznie, ale też ulega zmianom w ciągu życia jednostki pod wpływem kryzysów normatywnych i nienormatywnych. Zmiany te nie są bardzo intensywne i nie sięgają skrajnych wartości; mówi się o fluktuacjach wokół punktu bazowego dobrostanu, a jest to uwarunkowane głównie cechami osobowości jednostki i strategiami radzenia sobie w sytuacjach trudnych. Wyniki badań własnych wskazują, że wysokie natężenie stresu doświadczanego przez studentów w czasie pandemii choroby COVID-19 ma związek z poziomem ich dobrostanu psychicznego. Otrzymane wyniki są zgodne z dotychczasowymi ustaleniami badaczy na temat wpływu stresu na dobrostan psychiczny studentów (Denovan, Macaskill 2016), a w szczególności ten związek obserwuje się w czasie pandemii (Savage i in. 2021; Linden i in. 2020). Przedstawione wyniki badań powinny być poddane dalszej analizie, a badania w tym zakresie kontynuowane, tak aby ocenić, czy zmiany w zakresie dobrostanu psychicznego studentów są stabilne, czy być może po pierwszej i kolejnych falach pandemii studenci potrafią wypracować pozytywne, adaptacyjne mechanizmy, pozwalające im na optymalne funkcjonowanie w warunkach kryzysu zdrowotnego.

Podsumowując, należy podkreślić, że przed uczelniami wyższymi stoją nowe zadania polegające na wspieraniu studentów w zakresie zdrowia psychicznego, a także rozbudowaniu oferty programów wczesnej profilaktyki i interwencji, aby złagodzić wpływ COVID-19 na studentów doświadczających wysokiego poziomu stresu, który potencjalnie wynika z rosnącej izolacji społecznej spowodowanej pandemią.

\section{Bibliografia}

Baines T., Wittkowski A. (2013). A Systematic Review of the Literature Exploring Illness Perceptions in Mental Health Utilising the Self-Regulation Model. „Journal of Clinical Psychology in Medical Settings", nr 20, s. 263-274.

Bandura A. (1977). Self-efficacy: Toward a unifying theory of behavioral change. „Psychological Review", nr 84 (2), s. 191-215.

Bavel J.J.V., Baicker K., Boggio, P.S. i in. (2020). Using social and behavioural science to support COVID-19 pandemic response. „Nature Human Behaviour”, nr 4, s. 460-471.

Blanco C., Okuda M., Wright C., Hasin D.S., Grant B.F., Liu S.M., Olfson M. (2008). Mental health of college students and their non-college-attending peers: Results from the national epidemiologic study on alcohol and related conditions. „Archives of General Psychiatry", nr 65 (12), s. 1429-1437. 
Charles N.E., Strong S.J., Burns L.C., Bullerjahn M.R., Serafine K.M. (2021). Increased mood disorder symptoms, perceived stress, and alcohol use among college students during the COVID-19 pandemic. „Psychiatry Research”, nr 296.

Cohen S., Kamarck T., Mermelstein R. (1983). A global measure of perceived stress. „Journal of Health and Social Behavior", nr 24 (4), s. 386-396.

Cohen S., Janicki-Deverts D. (2012). Who's stressed? Distributions of psychological stress in the United States in probability samples from 1983, 2006, and 2009. "Journal of Applied Social Psychology", nr 42 (6), s. 1320-1334.

Cornelius-White J. (2007). Learner-centered teacher-student relationships are effective: A meta-analysis. „Review of Educational Research”, nr 77 (1), s. 113-143.

Crum A.J., Jamieson J.P., Akinola M. (2020). Optimizing stress: An integrated intervention for regulating stress responses. „Emotion”, nr 20 (1), s. 120.

Czapiński J., Panek T. (red.). (2015). Diagnoza społeczna 2015. Warunki i jakość życia Polaków. Warszawa: Rada Monitoringu Społecznego.

Denovan A., Macaskill A. (2017). Stress and subjective well-being among first year UK undergraduate students. „Journal of Happiness Studies”, nr 18 (2), s. 505-525.

Dębska U., Guła-Kubiszewska H. (2005). Samoregulacja, strategie uczenia się i style radzenia sobie ze stresem u młodych dorosłych. „Psychologia Rozwojowa”, s. 10 (4), s. 83-94.

Diener E., Seligman M.E. (2004). Beyond money: Toward an economy of well-being. „Psychological science in the public interest”, nr 5 (1), s. 1-31.

Doré B.P., Morris R.R., Burr D.A., Picard R.W., Ochsner K.N. (2017). Helping others regulate emotion predicts increased regulation of one's own emotions and decreased symptoms of depression. „Personality and Social Psychology Bulletin”, nr 43 (5), s. 729-739.

Elmer, T., Mepham, K., Stadtfeld, C. (2020). Students under lockdown: Comparisons of students' social networks and mental health before and during the COVID-19 crisis in Switzerland. „Plos one”, nr 15 (7).

Garfin D.R., Silver R.C., Holman E.A. (2020). The novel coronavirus (COVID-2019) outbreak: Amplification of public health consequences by media exposure. „Health Psychology”, nr 39 (5), s. 355-357.

Harding S., Morris R., Gunnell D., Ford T., Hollingworth W., Tilling K. i in. (2019). Is teachers' mental health and wellbeing associated with students' mental health and wellbeing? "Journal of Affective Disorders", nr 242, s. 180-187.

Hawkley L.C., Cacioppo J.T. (2010). Loneliness matters: A theoretical and empirical review of consequences and mechanisms. Annals of behavioral medicine, nr 40 (2), s. 218-227.

Helliwell J.F., Huang H. (2013). Comparing the happiness effects of real and on-line friends. „PloS one”, nr 8 (9).

Heszen-Niejodek I. (red.). (2002), Teoretyczne i kliniczne problemy radzenia sobie ze stresem. Poznań: Stowarzyszenie Psychologia i Architektura.

Husky M.M., Kovess-Masfet V., Swendsen J.D. (2020). Stress and anxiety among university students in France during COVID-19 mandatory confinement. „Comprehensive Psychiatry", nr 102. 
Ilska M., Kołodziej-Zaleska A. (2018). Dobrostan hedonistyczny i eudajmonistyczny w sytuacjach kryzysów normatywnych i nienormatywnych. „Zeszyty Naukowe. Organizacja i Zarządzanie/Politechnika Śląska”, z. 128, s. 155-184.

Kadzikowska-Wrzosek R. (2012). Siła woli a subiektywny dobrostan i poczucie autodeterminacji: moderująca rola stresu. „Przegląd Psychologiczny”. T. 55, nr 4, s. 347-367.

Kowal M., Coll-Martín T., Ikizer G., Rasmussen J., Eichel K., Studzińska A. i in. (2020). Who is the most stressed during the COVID-19 pandemic? Data from 26 countries and areas. „Applied Psychology: Health and Well-Being”, nr 12 (4), s. 946-966.

Kulawska E. (2019). Dobrostan psychiczny a poziom odczuwanego stresu i satysfakcji ze studiów $w$ doświadczeniach studentów pedagogiki przedszkolnej i wczesnoszkolnej. „Forum Pedagogiczne”, nr 2/2, s. 129-149.

Lazarus R.S., Folkman S. (1984). Stress, Appraisal, and Coping. New York: Springer.

Lent R.W., Singley D., Sheu H.B., Gainor K.A., Brenner B.R., Treistman D., Ades L. (2005). Social cognitive predictors of domain and life satisfaction: Exploring the theoretical precursors of subjective well-being. "Journal of Counseling Psychology”, 52(3), 429.

Linden B.; Stuart H. (2020). Post-Secondary Stress and Mental Well-Being: A Scoping Review of the Academic Literature. „Canadian Journal of Community Mental Health”, 39(1), 1-32.

Moksnes U.K., Moljord I.E., Espnes G.A., Byrne D.G. (2010). The association between stress and emotional states in adolescents: The role of gender and self-esteem. „Personality and Individual Differences", nr 49 (5), s. 430-435.

Pierceall E.A., Keim M.C. (2007). Stress and coping strategies among community college students. „Community College Journal of Research and Practice”, nr 31 (9), s. 703-712.

Raport UNESCO (2020). COVID-19 Educational Disruption and Response. Dostępny na: https://en.unesco.org/COVID19/educationresponse (otwarty: 20.04.2021).

Ryan R.M., Deci E.L. (200o). Self-determination theory and the facilitation of intrinsic motivation, social development, and well-being. „American Psychologist”, nr 55 (1), s. 68.

Ryan R.M., Deci E.L. (2001). On happiness and human potentials: A review of research on hedonic and eudaimonic well-being. „Annual Review of Psychology”, nr 52 (1), 141-166.

Ryff C.D. (2017). Eudaimonic well-being, inequality, and health: Recent findings and future directions. „International Review of Economics”, nr 64 (2), s. 159-178.

Savage M.J., Hennis P.J., Magistro D., Donaldson J., Healy L.C., James R.M. (2021). Nine months into the COVID-19 pandemic: a longitudinal study showing mental health and movement behaviours are impaired in UK students. "International Journal of Environmental Research and Public Health", nr 18 (6).

Schiep S., Cieślik K.A., Fila K., Bętkowska-Korpała B. (2013). Samoregulacja, lęk, depresyjność $i$ style osobowości osób zaabsorbowanych praca zawodowa we wczesnej dorosłości. „Psychologia Rozwojowa”, nr 18 (2), s. 49-64.

Son C., Hegde S., Smith A., Wang X., Sasangohar F. (2020). Effects of COVID-19 on college students' mental health in the United States: Interview survey study. „Journal of Medical Internet Research", nr 22 (9). 
Stecz P., Chanduszko-Salska J. (2010). Aktywność ruchowa studentów polskich i szkockich: motywy jej podejmowania a poziom odczuwanego stresu. W: Jakość życia-aspekty turystyczne i rekreacyjne. Kraków: Abaton, s. 141-152.

Struthers,C.W., Perry R.P., Menec V.H. (2000). An examination of the relationship among academic stress, coping, motivation, and performance in college. „Research in Higher Education", nr 41 (5), s. 581-592.

Taylor Z.E., Doane L.D., Eisenberg, N. (2014). Transitioning from high school to college: Relations of social support, ego-resiliency, and maladjustment during emerging adulthood. „Emerging Adulthood”, nr 2 (2), s. 105-115.

Tedeschi R.G., Calhoun L.G. (2004). Posttraumatic growth: Conceptual foundations and empirical evidence. „Psychological Inquiry”, nr 15 (1), s. 1-18.

Tennant R., Hiller L., Fishwick R., Platt S., Joseph S., Weich S., Stewart-Brown S. (2007). The Warwick-Edinburgh mental well-being scale (WEMWBS): development and UK validation. „Health and Quality of life Outcomes”, nr 5 (1), s. 63.

Turner J., Bartlett D., Andiappan M., Cabot L. (2015). Students' perceived stress and perception of barriers to effective study: impact on academic performance in examinations. „British Dental Journal”, nr 219 (9), 453-458.

Vaez M., Kristenson M., Laflamme L. (2004). Perceived quality of life and self-rated health among first-year university students. „Social Indicators Research”, nr 68 (2), s. 221-234.

Verduyn P., Lee D.S., Park J., Shablack H., Orvell A., Bayer J. i in. (2015). Passive Facebook usage undermines affective well-being: Experimental and longitudinal evidence. „Journal of Experimental Psychology", nr 144 (2), s. 480.

Waytz A., Gray K. (2018). Does online technology make us more or less sociable? A preliminary review and call for research. „Perspectives on Psychological Science”, nr 13 (4), s. $473-491$.

Wojciszke B. (2011). Psychologia społeczna. Warszawa: Wydawnictwo Naukowe Scholar..

Zajacova A., Lynch S.M., Espenshade T.J. (2005). Self-efficacy, stress, and academic success in college. „Research in Higher Education”, nr 46 (6), s. 677-706.

Zhang B., Yan X., Zhao F., Yuan F. (2015). The relationship between perceived stress and adolescent depression: The roles of social support and gender. „Social Indicators Research”, nr 123 (2), s. 501-518.

\title{
DISTANCE LEARNING, STRESS AND MENTAL WELL- BEING OF PEDAGOGY STUDENTS IN THE FIRST PHASE OF THE COVID-19 PANDEMIC
}

\begin{abstract}
The aim of this article is to assess the relationships between remote education, satisfaction with studies, the level of perceived stress during the COVID-19 pandemic and the general mental well-being of students. The research was carried out on 91 pedagogy students in June 2020. The results show that over 80 percent of students have a positive opinion of distance learning, and 34 percent are very satisfied with studying pedagogy.
\end{abstract}


Students' assessment of distance learning and their level of satisfaction with their studies are not related to psychological well-being. More than half of the surveyed students show high levels of stress in the first phase of the pandemic. Students experiencing lower levels of stress assess distance learning better than students who experience high levels of stress. Regression analysis shows that the level of stress experienced by students affects their psychological well-being. As the intensity of stress increases, there is a decline in mental well-being. Thus, students have been significantly affected by the COVID-19 pandemic.

Key words: remote education, stress, well-being, student of education, COVID-19. 